\title{
Analysis on Penetrative Effects of New Media on Ideological and Political Education of Universities and Colleges
}

\author{
Liping Zhang \\ College of Elementary Education, China West Normal University, Nanchong, China \\ Email: guicaitang@163.com
}

Received 23 November 2015; accepted 27 December 2015; published 30 December 2015

Copyright (C) 2015 by author and Scientific Research Publishing Inc.

This work is licensed under the Creative Commons Attribution International License (CC BY). http://creativecommons.org/licenses/by/4.0/

c) (i) Open Access

\begin{abstract}
The growing development of science, technology and information makes media such as computer and mobile phone become essential parts in our daily life and play a vital role in students' physical and mental development. With rapid development of science and technology at present, new media such as computer and mobile phone has become an essential part of our daily life. As the important platform to cultivate high-quality talents, colleges play a crucial role in the development of society. Colleges should know clearly about the important responsibilities shouldered by them. According to students' characteristics, they should achieve effective combination of ideological and political education and new media, give full play to the huge advantages of new media, and use its characteristics such as enormous information and rapid propagation speed to realize its effective use in ideological and political education. This article analyzes the problems of new media existed in ideological and political education in colleges, puts forward countermeasures of new media to penetrate into the ideological and political education in colleges and lays foundation for the penetrability of new media in ideological and political education in colleges.
\end{abstract}

\section{Keywords}

New Media, Universities and Colleges, Ideological and Political Education, Problems, Penetrability, Measures

\section{Introduction}

New media represented by network technology and mobile communication technology develops rapidly and has multiple effects on human society. It involves almost all the aspects such as political form, consciousness and 
concept, cultural tradition, commercial economy and educational development. New media runs through campus life in colleges and changes students' learning, life and way of thinking. At the same time, it also brings new opportunities and challenges for ideological and political education work in colleges. In terms of opportunities, characteristics of new media such as massive amounts of information, resource sharing, rapid interaction and vivid image create new carriers and new platforms for ideological and political education in colleges and enrich the form and content of ideological and political education for college students, "people who master the information and control the internet will possess the whole world". Effectively using new media can enhance the effectiveness of ideological and political education work for students; in terms of challenges, new media is also a "double-edged sword" and it is virtual, open, concealed and difficult to control. All of these characteristics make ideological and political education in colleges face new challenges. It is in urgent needs to renovate conceptions and methods of ideological and political education in colleges. In face of new opportunities and challenges, it is necessary to concentrate efforts on improving the quality of media, expanding ways of education and renovating educational strategy.

The so-called new media refers to a kind of burgeoning media form that develops after the emergence of traditional media such as newspaper, broadcast and television and mainly includes modern network media, digital television, electronic press and mobile phone, etc. It is an ever-changing concept with the development of technology. Constant confrontation among the present burgeoning media cultures has powerful influence on the general public. New media not only changes the existing social life, but also anew shapes the form of our daily life. At present, new media has become an important way and the main platform for college students to understand information and acquire knowledge. It usually includes email, QQ, microblog, WeChat and short message, etc. According to relevant investigative data, it shows that by the end of June in 2011, net citizens under 30 years old in our country account for 58 percent of the total number and college students are the main force. With continuous impact of new media, the influence and spreading force of traditional media are reduced and weakened gradually. New media occupies the market on a large scale with its large quantity of information, strong interaction, wide spread and timeliness and has become an essential and important part in college students' daily life [1].

\section{Problems of New Media Existing in Ideological and Political Education Work in College}

\subsection{Internationalization and Nationalization Lack Balance in the Interaction}

New media mainly takes internet and digital technologies as the whole supporting system. The emergence of new media has great impact on traditional education platform. The face-to-face communication, letter communication and telephone conversation in the past have been replaced by modern media such as the burgeoning QQ, microblog and WeChat. These burgeoning media break the limitations of time and space, and have powerful function of information search, more comprehensive coverage and diversified forms. With the development of current globalization, the ideological and political education work for college students pays more and more attention on the unification of globalization and nationalization. At present, college students can know more and more national culture, religion and ideology on the platform of new media. However, in the process of interaction, mutual collision between cultures will inevitably happen. All aspects powerfully strike the position of ideological and political education in colleges [2]. Western ideologies and cultural achievements directly or indirectly have influences on the form and development of college students' view of life and world outlook through continuous spread of new media, and form powerful supremacy in culture and information. These influences will greatly surpass achievements obtained by traditional education, and then it will make college students lose their concepts and go astray in the process of growing up.

\subsection{There Are Contradictions between Reality and Virtuality}

New media is widely welcomed by college students and has effects on them. Especially the virtuality of network derived from multimedia technology makes college students excessively get addicted to it, great changes have happened in students' thoughts and behaviors. Some students find sense of presence and satisfaction in virtual world of the internet because their demands in interpersonal relationships and study and work cannot be met in reality. But if every student looks for a harbor of refuge in the cyber world when facing setbacks in reality, and 
if things go on like this, students' psychology will lose balance inevitably. What's more, because of the imperfection of the law, there are no complete laws to regularize and guarantee the virtuality of new media, it is difficult to verify students' behaviors and whether the words said by them are true or not. The continuous conflicts between reality and virtuality through comparison will deepen the contradiction in students' mind, and leads to egoism and individualism.

\subsection{Imbalance Exists between Limitations and Freedom}

Because of the uniqueness of new media, it gives college students freer and private interaction space of information. But without certain regulations and rules, it is easy to go into uncontrollable situation. What's more, students in colleges belong to the sensitive group and haven't formed relatively mature world outlook and view of life, and they don't have good abilities to identify and resist bad information. Some students know that the new media has limitations, so they recklessly spread undesirable pornographic information and violent information on the internet. The unhealthy information has a serious effect on the environment of new media and campus environment in colleges. If things continue this way, students will lose the ability of rational judgment, and then their mind and bodies will suffer from destroy and persecution at different levels, which severely disrupt the ideological and political education work in colleges.

\section{Analysis on the Penetrating Approaches of New Media in Ideological and Political Education in Colleges}

\subsection{Diversification of Penetrating Approaches}

At present, the ideological and political education in some colleges still uses the way of traditional theoretical inculcation and simply relying on expounding knowledge mechanically. However, with continuous improvement of today's society and dramatic development of science and technology, college students' thoughts and horizons are also enriched. Therefore, shortcomings of traditional ideological and political work gradually expose. While new media has huge amount of information, flexible interactive form and can spread rapidly. Students can speak out freely on this new media platform. Educators of ideological and political education in colleges also can actively interact with students on this platform, so that they can timely know the newest ideological trend and real ideas of students. Once finding problems, they can solve them in time, which greatly improve the timeliness and efficiency of ideological and political education work. In new media time, ideological and political educators must master certain skills to apply new media to improve the effect of education. The skill to spread new media is an important aspect of media application skill and it is the strategy and method adopted in the activities of transmission in order to effectively achieve the expected purpose. Educators can transmit knowledge to students effectively and make it easier for them to accept through imparting corresponding skills. In the information era, ideological and political educators should skillfully make the most of advantages of new media, carry out vivid and attractive ideological education that has influence and infection, and implement the ideological and political education work through various channels and diversification to strengthen the effect of education.

\subsection{Renovate the Idea of Ideological and Political Education}

Under new media environment, the idea of ideological and political education should take modernization and informatization as the guidance, make efforts to change educational idea of ideological and political educators, enhance their cognitions and understandings for new things and make them dare to innovate boldly in teaching practice. First of all, it's necessary to fully realize the important role that new media plays in ideological and political education work, know the influence that new media has on college students in aspects such as cognitive style, way of thinking, psychological behavior and values, and then see clearly about the opportunities and challenges brought by new media for ideological and political education work and actively integrate it into the innovative ideas of ideological and political education. Secondly, it's essential to cultivate ideological and political educators to have new media service concept of "people first", establish the service view of ideological and political education, put the services for students in the first place, use the convenient information transmission channel of new media to help students to grow up and become useful persons, thus cultivate a team of ideological and political educators who have relatively high service concept, educational experience, and can expertly 
master the new media technology and know characteristics of new media well, and then continuously and consciously improve media literacy. Learning environment established under new media technology will change the traditional rigid "preach", reduce college students' negative attitudes toward ideological and political education, integrate media elements such as words, voice, image and video, give play to students' principal role in education [3]. Through carrying out investigative study on the internet, teachers and students cooperate and actively develop all kinds of curriculum resources, give play to the timely function of communication of new media, update teaching materials in time, make the contents of ideological and political theory course more fashionable, more substantial, and the form become more vivid, and then enhance the classroom interaction of ideological and political theory course and promote the effectiveness of ideological and political education in colleges. At the same time, use new media technology to realize the interaction of ideological and political theory course after class, use the carrier of excellent course to spread teaching contents of ideological and political theory course such as video classroom, network courseware, answering questions after class and investigative study, etc. through topic-learning websites, expand the coverage and radiating surface of teaching contents and strengthen the influence and attraction of teaching results.

\subsection{Broaden Students' Horizons}

As the basis of the generating of new media, and one of the greatest inventions in the 20th century, the internet plays an irreplaceable role in our daily life. Contemporary college students grow up under the powerful influence of network, therefore, compared with the previous generation, they have broader horizons and novel thoughts. They excessively pursue newfangled things and do not like to follow the same pattern. Therefore, in order to better master the dynamic condition of students' physical and mental development, ideological and political educators also need to grasp certain new media technology and use new media to replace traditional education mode gradually. In this process, ideological and political educators must make up for the inadequacy of their own capabilities, at the same time, they have to know more advanced educational ideas and methods through new media and formulate reasonable educational plans and methods according to practical situation. Besides, using new media can also timely master the thoughts spread by the internet and then guide students correctly. Colleges can make the best of new media platform of ideological and political education, take campus network as the new platform of ideological and political teaching under new situation and further expand approaches of education. Firstly, establish special website for ideological and political education, actively and vigorously publicize basic theory, basic line and basic program, carry out socialistic education, the ethos education, moral education and basic quality education of citizens in a deep-going way, and correct their attitudes toward outlook on life, world view and value. Secondly, strengthen the construction of campus network, make the best of the rapid, vivid, convenient and open advantages of network, build the network platform of mainstream ideology for students to acquire information, learn knowledge and exchange ideas, open up characteristic home page of network, carry out the publicity and communication of main plates such as current news, law popularization, environmental protection, love and charity, social practice and quality-oriented education, and widely implement colorful three-dimensional interactive activities of "online interaction and offline joint action". Meanwhile, set up host unit to release information section of all kinds of positive information, and pay attention to students' growing and provide college students with services such as learning, employment and psychological counseling, etc. They should also take the measures of combination of enlightenment and eradication, pay close attention to harmful trends in college campus through campus network, quickly make judgments, responses and clarification and eliminate negative effects that public feelings and public opinions on the internet have on college students. Thirdly, it is helpful to rely on campus network to establish the team of ideological education work and form the organization of network management. Establish a volunteer team of network formed by ideological and political educators, course teachers, student cadres, and network administrators of students and parents of students to positively be active in forums of campus network, timely shield or delete wrong information and release healthy and progressive posts and maintain good network environment and advocate surfing the internet with healthy and civilized behaviors.

\subsection{Enrich the Resources of Ideological and Political Education in Colleges}

New media has furthest realized the spread and sharing of resources by using network technology as the main medium. When we want to learn knowledge of a subject in the course of study and know the life story of a great 
man, we can search by way of the new media. In the process of implementing ideological and political education work, colleges use new media technology to intuitively and vividly show correct value and outlook on life that conform to the spiritual outlook of college students in front of students, thus students will have impressive experience. Meanwhile, with the help of powerful quantity of resource of new media, educators can show information in aspects such as excellent cultural tradition in our country and history of struggles of Chinese Communist Party to students through vivid pictures, and then add vivid explanation, so it can better cause the spiritual resonance of students. Students will actively and initiatively accept ideological and political education, make their words and deeds better conform to socialistic ethic and establish correct outlook on life and world view. In the era of new media, all kinds of websites have become important spreader of information and important power to influence people's thoughts and behaviors, but now the phenomenon of ecological degradation of network culture is serious. It helps to boost the ideological and political education in colleges in a certain sense by supporting mainstream of network cultural force, constructing websites of mainstream of ideological and political education and forming positive public opinions. The construction of mainstream of ideological and political education websites should base on positive development and sharing of information resources, plan comprehensively and promote steadily. Firstly, adopt lively and vivid forms that people are delighted to hear and see to truly realize equal, effective, keen and detailed education and communication on the internet; secondly, expand the coverage of web-based ideological and political education, permit news propaganda organizations, cultural organizations and Communist and Youth League organizations to enter the internet, promote the appeal and advantages of network itself; thirdly, increase the development of web-based ideological and political education software, make and spread ideological and political education software that integrate thoughts, knowledge, interestingness and art, edify students with great and profound excellent cultures of Chinese nation, and then receive good effects of ideological and political education [4].

\section{Conclusion}

Modern information technology has greatly promoted the development and progress of human society. With continuous update of science and technology, the replacement cycle of new media is shortened tremendously. As successors of our country and young people who are brave and have entrepreneurial spirits in this era, college students always walk in the forefront of age and are embraced by various kinds of new media. The continuous change of new media environment not only has huge influence on the present cultural environment and education of colleges, but also has different levels of effects on college students' socialization. Colleges need to know well about the important responsibilities shouldered by them, change traditional educational idea, pay attention to the diversification of educational channel, continuously broaden students' horizons and enrich the resources of ideological and political education, promote the efficiency of classroom teaching and cultivate professional talents who can meet the requirements of social development.

\section{References}

[1] Hao, M. (2014) Analysis on Penetration Function of New Media in Ideological and Political Education in Colleges. Journal of Hubei University of Science, No. 9, 144-145.

[2] Zhang, H.N. (2012) Discussion on Application of New Media in Ideological and Political Education in Colleges. Journal of Yan'an Vocational and Technical College, 6, 32-43.

[3] Zhang, S. and Yu, X.F. (2012) Implicit Education of Ideological and Political Work in Colleges under New Media Environment. Journal of Tongling College, No. 4, 80-82.

[4] Liu, J. (2014) Research on Application of Ideological and Political Education in Colleges under New Media Environment. Journal of Knowledge Seeking, No. 11, 10-11. 